\title{
pro.posıções
}

$e$-ISSN 1980-6248

http://dx.doi.org/10.1590/1980-6248-2017-0028

CRITICAL LITERACY

\section{Waiting for Superman: A cultural studies analysis in the nightmare of the present}

Gabriel Huddleston (i)

Robert J. Helfenbein (ii)

(i) Texas Christian University -TCU; Fort Worth, TX, United States of America; https://orcid.org/0000-0001-5219-903X.g.huddleston@tcu.edu

(ii) Loyola University Maryland, Baltimore, MD, United States of America; rjhelfenbein@loyola.edu

Abstract: While the history of cultural studies cites origins in adult education and
contemporary scholars continue to note the need for cultural studies work in
schools the connections between cultural studies and educational theorizing seem
strained. This paper suggests the recent film Waiting for Superman offers an
opportunity for a cultural studies analysis with clear import on education and
curriculum theorizing. In specific, this paper notes the important conjuncture of
forces at work in the public discourse of so-called education reform in the
contemporary US context and suggests that cultural studies analysis may be
needed now more than ever. This offering provides linkages between the
discursive construction of educative reform efforts, the material lived experiences
of those who spend time in educative contexts, and the concomitant ethics that
such constructions require. As free-market fundamentalism, neoconservative
ideological formations, and representations of school and schooling are all in play,
this perspective-both in the material and academic sense-intends to help
reinvigorate the conversation between cultural studies and curriculum theorizing
and provides new understandings of this "nightmare of the present".
Keywords: curriculum theory, cultural studies, neoliberal education reform

These days, it seems that every crisis needs a documentary. For the crisis that is the United States public education system, that documentary is Waiting for Superman (Chilcott, Guggenheim, \& Kimball, 2010). This work begins from the position that popular culture phenomena hold rich possibilities for educational researchers (Helfenbein, 2007). Our position can be characterized simply: Representations of teachers and schooling matter. Culture, in our view seen as a process rather than a thing, involves the ways in which meaning 


\section{pro.posıções}

$e$-ISSN 1980-6248

http://dx.doi.org/10.1590/1980-6248-2017-0028

is made of self, society, and the myriad interactions that inform social practices (Fiske, 1989). Therefore, the ways in which the institution of schooling is represented in a popular text reflect, at least to some degree, popular conceptions of governmental institutions, schooling, teachers, the larger public sphere, and the ways in which they interact. It is important to note that both Fiske and Helfenbein offer that a film can be read as text, and that this text is not scholarly in nature but, rather, one of popular culture - a term acknowledged as problematic at best and persistently debated amongst cultural studies scholars (Johnson, 1996). The ways in which dominant ideologies are at work in texts like the film Waiting for Superman provide insight both into the power of the logic of educational reform but also into what representations of school and schooling resonate with a larger public (regardless of political leanings). However, because of the dependence on the pleasure of the reader, popular culture texts must necessarily be popular. This simple a priori statement compels cultural studies scholars to attend to a diversity of readers/readings and at least opens the possibility that some readings may be resistive. In other words, while dominant ideologies may be at work in the creation of popular texts, their dominance is in no way guaranteed as one considers the ways in which they are read. As Fiske (1989) states, "there is always an element of popular culture that lies outside social control, that escapes or opposes hegemonic forces" (p. 2). In this way, popular culture always operates on the level of the semiotic and reflects the tension between ideological forces in its production and the unpredictable possibilities in the reading of texts. This paper explores precisely those spaces of escape or opposition in relation to the forces in education that may be hegemonic.

Indeed, it is our belief that this film presents an opportunity, bordering on an imperative, to connect cultural studies, as articulated by Hall, to a curriculum theorizing that exams hegemonic forces in education deemed by Pinar (2004) as a nightmare. Such a conversation between cultural studies and curriculum theorizing presents a framework and methodology for examination in which other tools can be used to dig deeper. This paper demonstrates this by beginning with cultural studies and then picking up some selective tools to work on the film.

Perhaps the reason that we see Waiting for Superman as such an opportune moment of critical examination is the notoriety it has gained, becoming a touchstone in the education reform debate. The movie's director, Davis Guggenheim, garnered some sense of distinction 


\section{pro.posıções}

$e$-ISSN 1980-6248

http://dx.doi.org/10.1590/1980-6248-2017-0028

from directing An Inconvenient Truth. Guggenheim's association with the documentary was perhaps overshadowed by the film's main focus, Al Gore, but in the poster for Waiting for Superman the heading reads, "From the director of An Inconvenient Truth." Guggenheim's own personal narrative was tied closely to the creation of Waiting for Superman, as he has been quoted as being inspired to make the documentary when driving his own children to their private school past the public schools they would have attended if not for Guggenheim's ability to send them somewhere else (Couric, 2010).

The movie was released on October $8^{\text {th }}, 2010$, seemingly to coincide with the start of the traditional school year. As a lead up to the movie's opening, Guggenheim and Bill Gates appeared on "The Oprah Winfrey" show to promote not only the film, but some of the efforts of Gates' educational reform organization, The Bill and Melinda Gates Foundation. Subsequently, the movie's producers launched a major web campaign. The website itself had a countdown clock to the release and asked visitors to make a pledge to see the movie. Guggenheim wrote entries for The Huffington Post, which ran ads and linked articles to the movie as well.

The movie's main focus is on several students and their current places within the American educational system. All of the students are either currently, or eventually in the public school system, but are looking for ways out of the system and into charter schools, which have a limited number of available openings and must all hold public lotteries to choose which students are allowed in. The end of the film culminates in these lotteries that determine whether the students gain admittance.

The film is far from an objective look at public schools in the United States. In addition to examining the supposed problems in education, the film also constructs a very specific version of educational reform. To begin, the film presents knowledge as a desirable commodity, the result of an obscured, simplified production process. The film also relies on a Bush-era understanding of free-market logic as applied to the public education system that is best exemplified in the policies of No Child Left Behind (NCLB), often referred to as neoliberal education reforms. NCLB ushered in a wave of educational reform, that along with free-market principles relied on standardized testing and led to a widespread demonization of teachers (Ravitch, 2010; Taubman, 2009). This attack on teachers was focused on teachers' unions and the shortcomings of the tenure system found in most schools. The film does little 


\section{pro.posıções}

$e$-ISSN 1980-6248

http://dx.doi.org/10.1590/1980-6248-2017-0028

to refute these ideas but, instead, takes them as givens. Combined with the film's lack of evidences and its failure to contextualize social factors as they relate to education, this is truly problematic. However, the purpose of this paper is not only to point out the film's flaws, but also to ask: How might cultural studies point to new understandings of the popular discourse on public education? And, how might curriculum scholars respond?

Indeed, as we have alluded to before, Waiting for Superman represents a space of possibility that could lead to meaningful examination and dialogue. However, for this to happen, we believe, through the use of cultural studies, two things must be insisted upon. The first is that those opposed to neoliberal education reform efforts cannot portray the film as the poster child for such reforms. Cultural studies, Stuart Hall especially, rejects dichotomous thought in which things are either one thing or the other. It is our contention that Waiting for Superman is neither propaganda nor benign movie fodder, but rather a point at which a multitude of interpretations spring forth, and it is there that work must be done. Secondly, to engage with these interpretations is to work towards the material in a way that, we believe, should guide the discussions of those in the fields of cultural studies and curriculum theorizing. The interpretations of the film are not trifle little things, but the thoughts of politicians, teachers, parents, students, scholars, etc. that hold real, tangible consequences.

\section{NCLB and Waiting for Superman-A brief history of No Child Left Behind and its legacies}

In the decade preceding the release of the film, a gathering storm gained momentum in the world of education reform. It began with the passage of No Child Left Behind (NCLB) in 2001. At the time, NCLB was the largest federal program the United States had ever seen regarding a national education policy. Most surprising was the legislation's chief backer and champion, Republican president George W. Bush. Surprising because the Republican Party had notoriously bristled at large, federally-mandated programs in regard to education. Their disdain for such programs was most evident by President Ronald Reagan's desire to get rid of the Department of Education. Several factors could account for the passage of NCLB: the brief bipartisan feeling after the events of September $11^{\text {th }}$, the apparent success of Bush's reform of the Texas education system when he was governor, and both the Right's and the 


\section{pro.posıções}

$e$-ISSN 1980-6248

http://dx.doi.org/10.1590/1980-6248-2017-0028

Left's frustration with an apparent stagnation in educational reform efforts of the past. Diane Ravitch (Ravitch, 2010) points to various other contributing factors, including the early 1980's A Nation at Risk (Gardner, 1983). Whatever factors contributed to the passage of the legislation, its effects were sweeping and immediate, resulting in a fait accompli in terms of the use of free-market principles in educational reform.

Almost ten years later, NCLB had spawned a wave of reforms and had caused significant changes in the landscape that is education in the United States. To begin, it would be helpful to focus on the two main tenants of NCLB that Ravitch (Ravitch, 2010) and others (Pinar, 2004; Taubman, 2009) have shown to be the most influential: "accountability" and "choice." NCLB looked to hold accountable the schools that were deemed as failing to provide their students with a solid education. To determine whether a school was failing, standardized tests were used. These tests were given annually from the $3^{\text {rd }}$ grade to $8^{\text {th }}$ grade with two more tests in $10^{\text {th }}$ and $12^{\text {th }}$ grades. Initially, these tests were given in Math and English, but have since expanded to Social Studies and Science (United States Department of Education, 2010). States were given leeway to design their own standards in relation to these tests or to adopt nationally prescribed standards (Ravitch, 2010; Taubman, 2009). If, after limited attempts to turn around their low scores on these tests, a school was still designated as failing, parents were allowed to move their children to a non-failing school. This points to the second component of NCLB, which is "choice."

NCLB sought to give parents the freedom to choose where their children attended school. In the end, the logic held, the nation's school system would resemble the free market; bad schools would close, while good schools would grow and flourish. In reality, few bad schools have been closed, and charter schools-publicly funded schools that are able to circumvent collective bargaining and school district regulations-have grown in number while producing mixed results (Raymond, 2009Raymond et al., 2009). This has also led to teachers becoming the main source and target of ire for school reformers. Whereas the initial aim of NCLB was to hold schools accountable, reform in the spirit of NCLB has sought to hold individual teachers accountable as well, tying pay to student performance and seeking ways to eliminate tenure.

We avoid diving into the complexities of NCLB for fear that such a diversion would overshadow the purposes of this paper. Indeed, NCLB has morphed into the Obama 


\title{
pro.posıções
}

$e$-ISSN 1980-6248

administration's own version of it, called Race to the Top (RT'TT), which has continued and enforced its policies. RTTT major difference from NCLB is that it seeks to reward, while NCLB sought to punish. More specifically, RTTT uses stimulus money to award grants to states and their proposed education reforms. However, these reforms must be in line with the reforms supported by the current administration, such as charter schools, tying teacher pay to accountability, breaking the unions, and ending teacher tenure (Ravitch, 2010; Taubman, 2009). The underlying goal of such reforms is the opening up of the public-school sector to private investment. So, while the policies of RTTT are not mandated universally, they are seeking to tie monetary resources to policy, in order to shape the policies in different states.

While we avoid delving into more specifics here, it is helpful to keep in mind moving forward a working definition from Harvey (2005) that offers the basic tenets of neoliberalism:

\begin{abstract}
Neoliberalism is in the first instance a theory of political economic practices that proposes that human well-being can best be advanced by liberating individual entrepreneurial freedoms and skills within an institutional framework characterized by strong private property rights, free markets, and free trade. The role of the state is to create and preserve an institutional framework appropriate to such practices. The state has to guarantee, for example, the quality and integrity of money. It must also set up those military, defence, police, and legal structures and functions required to secure private property rights and to guarantee, by force if need be, the proper functioning of markets. Furthermore, if markets do not exist (in areas such as land, water, education, health care, social security, or environmental pollution) then they must be created, by state action if necessary. But beyond these tasks the state should not venture. State interventions in markets (once created) must be kept to a bare minimum because, according to the theory, the state cannot possibly possess enough information to second-guess market signals (prices) and because powerful interest groups will inevitably distort and bias state interventions (particularly in democracies) for their own benefit. (p. 2)
\end{abstract}

This definition plays out in the education reforms mentioned earlier. However, it also speaks more broadly to neoliberalism's application in an ongoing attack on the public sector. Education is a small part of a larger movement in the United States which relies on the application of the free market in all spheres and the assumption of a hyper-rational individual.

\section{Waiting for Superman and free-market reform}

To begin, it might be helpful to present the storyline of the film in more detail along with the typical characteristics of a documentary that the film contains. The film follows what has become the traditional elements of a modern-day documentary. It uses voiceover (the 


\section{pro.posıções}

$e$-ISSN 1980-6248

http://dx.doi.org/10.1590/1980-6248-2017-0028

narrator is Guggenheim), interviews with the subjects of the film and with educational experts, animation, clips from the news, and historical footage. The overall focus of the film is on five children and their struggles within the public educational system. All of the students are in the public education system, but are seeking admittance to more exclusive charter schools. The film documents the failure of each student's respective public school and posits the charter schools as their "way out." Through the students, we meet their families and their schools. At the end of the movie each student attends a lottery to find out if they gained admission to a charter school.

The first student we meet is fifth-grader Anthony, an African-American boy residing in Washington D.C. who lives with his grandparents due to his father's death and his mother's addiction to drugs. Anthony applies to the SEED Charter School, which is an inner city boarding school. Initially, Anthony does not get into the school of his choice, but, in an epilogue, we find out that he eventually does. Each subsequent student is a variation on Anthony. Francisco is a Latino first-grader in the Bronx, Daisy is a Latina fifth-grader in East Los Angeles, Bianca is an African-American kindergartner in Harlem, and Emily is a white eight-grader in Silicon Valley. Of all the students, only Anthony and Emily gain admittance to their respective charter schools. It is interesting that all of the minority students come from inner-city public schools and the lone white student is from a suburban school district. This further reinforces stereotypes of these types of schools, inner-city schools serve minorities and suburban schools remain the property of whites. This trope becomes important later as we think about who is saving whom and, of course, the critical question of who gets to decide.

The movie builds its narrative structure upon key tenets of free-market reforms and ignores some of the problems inherent therein. The first tenet is the use of standardized testing to lay the groundwork for accountability amongst schools and teachers. The film begins with the passage of NCLB and with President Bush telling America's students that although they might not like tests they better get used to taking them. The film constantly refers to the results of these tests, either showing low reading scores state by state or comparing national scores to other countries, demonstrating how low the United States ranked in comparison. Not once does the documentary call into question the accuracy of these tests, let alone whether standardized testing is the most effective means to measure student knowledge. 


\section{pro.posıções}

http://dx.doi.org/10.1590/1980-6248-2017-0028

$e$-ISSN 1980-6248

Taking the role of standardized testing for granted in education allows the film to easily move to accountability. By focusing on low test scores, the film posits the idea of schools as "dropout factories", now a common pejorative term in public conversation on education, since these schools have a very low four-year graduation rate. In discussing this point, the Guggenheim makes the claim that the old way of thinking is to believe that the communities in which these schools are situated are mostly to blame for the high dropout rate, but now, there is evidence that the schools are mostly to blame. It is difficult to pinpoint exactly the evidence upon which the film relies. For example, the one study the film does cite only measures the dropout rates in certain schools, but does little to uncover the actual causes. It is here that the film makes its move towards the main crux of its argument: the reason these schools are failing is because of bad teachers.

The film relies on some broad generalizations and one isolated example to arrive at this perceived problem. The title of the film comes from the assertion that students are waiting for a Superman to come in and save the day in the form of good teachers, calling up images of a miraculous savior. While the film does highlight some examples of good teaching, it mainly stresses that there are far too many bad teachers out there and that the system is constructed in a way so that we cannot get rid of them. Its argument focuses on teachers' unions and the establishment of tenure to protect jobs. To be fair, the film does acknowledge, briefly, that tenure and unions were established initially to protect teachers from unjust firings. However, the film then goes on to say the tenure system and the unions that support it make it nearly impossible to fire bad teachers. To substantiate this assertion, the film presents Randi Weingarten, the head of the National Federation of Teachers, as a demagogue, intent on protecting all teachers no matter how bad they might be. They also highlight the process it takes to fire teachers as arduous, bureaucratic, and outdated. While teacher unions might be part of the problem in education, the film simplifies the discussion by framing unions as the main source of all problems. Such a position makes working with unions nearly impossible and further polarizes the participants in education reform.

The most glaring problem with the strategy of firing bad teachers is related to not questioning what to do next. Do you overburden the good teachers with more students? Are you going to hire more teachers? If so, from where are you going to hire them? Given that over $50 \%$ of teachers quit within the first five years to begin with, most school systems are 


\section{pro.posıções}

$e$-ISSN 1980-6248

http://dx.doi.org/10.1590/1980-6248-2017-0028

working from an ever-diminishing pool of qualified teachers (Carroll, 2007). The film never begins to broach any of these questions.

If public schools house nothing but bad teachers, according to the logic of the film, charter schools are bastions of learning (largely due to their lack of union affiliation and their position outside of traditional education bureaucracies). The film's focus on the students who are trying to gain admittance into the charter schools make it seem as though the students' only hopes for their futures rest on admission into these schools. This is unfortunate for several reasons. The first is that, on the whole, charter schools are remarkably similar to public schools. There are some very good ones, some downright lousy ones, and a many more inbetween (Raymond et al., 2009). The film just assumes that these schools are better, but only relies on two factors to determine that some specific charter schools are better than their public counterparts. The first is standardized test scores; the second is the dropout rate. What the film fails to address is that by limiting the number of students these schools admit, they are thereby limiting the potential social issues that each student may face. Another missed point is that the parents that choose to send their children to charter schools are usually the ones who are motivated to help their children to learn in the first place, putting their children at a marked advantage than some fellow students at low-performing public schools (Ravitch, 2010).

\section{Cultural studies analysis and education reform}

Perhaps the most interesting way to look at the film is through a lens inspired by Stuart Hall's (1992) explication of encoding and decoding. Specifically, a deconstruction of the film's overall message through Stuart Hall's work provides a tool for the continued thinking through of a new cultural studies of education. Invoking Hall brings cultural studies analysis to bear not only on the film itself, but on the current state of educational reform and the ways in which the discourse operates in wider, complex social context. As an analytic field, cultural studies embraces a theoretical approach to the study of interactions between the lived experiences and interpretations of people and the social structures that act upon and encode meaning to those experiences (Dimitriadis \& Carlson, 2003; Grossberg, Nelson, \& Treichler, 1992). This analytic approach was born out of television/media studies, but can be applied in 


\section{pro.posıções}

$e$-ISSN 1980-6248

other instances where an object is produced with an inherent message. In other words, an object, in this case a popular culture film, is encoded with a certain message much in the same way language is encoded with meaning. Indeed, encoding and decoding see these objects as others have seen language itself. Hall (1996) writes

Production, here, constructs the message. In one sense, then, the circuit begins here. Of course the production process is not without its discursive aspect [emphasis added]: it, too is framed throughout by meanings and ideas: knowledge-in-use concerning the routines of production, historically defined technical skills, professional ideologies, institutional knowledge, definitions and assumptions, assumptions about the audience and so on frame the constitutions of the programme through this production structure. Further, though the production structures of television originate the television discourse, they do not constitute a closed system. (p. 108)

In other words, the encoded message of an object is not guaranteed to remain constant. It will change once it is put out for public consumption. Hall (1996) continues, "At a certain point, however, the broadcasting structures must yield encoded messages in the form a meaningful discourse" (p.109). When this happens, the object gains a message that is different from the original encoding. The parameters of this paper limit further discussion of the subtleties of Hall's theory, but it is important to note that the decoding can either be in line with the original encoding or differ in varying degrees.

Hall's concept of encoding/decoding becomes relevant when one looks at the way in which Waiting for Superman was made and the way it was promoted. In both senses Guggenheim and the film's producers were carefully constructing the film to encompass educational reform as a whole. While the filmmakers claim that it was ostensibly created as a conversation starter, by encoding the film with arguments for testing, accountability, choice, charter schools, and ignoring social issues, the conversation presented a one-sided polemic. As Rudick (2012) notes, the film, and its subsequent marketing campaign, had the intent of shaping public opinion regarding school reform. What has been encouraging, from the point of view those who oppose free-market reforms, is that when the decoding of Waiting for Superman occurred many refused to take the initial encoding for granted. In other words, whether the filmmakers truly intended to start a conversation or not, they surely did-there were no guarantees over how the conversation would develop. 


\section{pro.posıções}

$e$-ISSN 1980-6248

The evidence of this type of decoding can been seen in one particular Web site and its Facebook companion, Not Waiting for Superman. The concept is simple enough, both sites take issue with the film, point by point. They also offer links to find out further information that debunks many of the claims the film tries to make. In addition, both sites will point visitors to where Davis Guggenheim or the film supporters are posting articles on other Web sites that promote the film, so they can make their own opinions heard in the comment sections of these posts. What has been interesting is that the decoding has had an effect on the continual encoding that Guggenheim engaged during the ongoing promotion of the film. During the promotion, Guggenheim posted articles on the Huffington Post. The tenor of these articles changed as negative reaction, in the form of the aforementioned decoding, grew. Below are the titles and a selection of excerpts from each of the posts.

Repeat After Me: We Can't Have Great Schools Without Great Teachers (Guggenheim, 2010b).

So when the conversation about how to fix our school feels too complicated and overwhelming, just think of one thing: we can't have great schools without great teachers. Repeat after me: We can't have great schools without great teachers. And when you start with that simple truth, the solutions become pretty clear.

The Teacher Who Changed My Life (Guggenheim, 2010c)

As we debate the complex issue of education, it feels overwhelming and confusing, and it is easy to forget that great teachers are at the heart of fixing our schools.

Do You Dither? (Guggenheim, 2010a)

You can divide the education world into two camps. No, not democrat or republican. Not incrementalist or disrupter. Or even pro-union or pro-charter. The best way to know whether you are on the right side of school reform is determined by how you answer these two questions: Do you dither? Or do you do?

When I hear thoughtful criticism of Waiting For "Superman" I am energized because I am seeing the movie work-I realize it's only 90 minutes and it can't answer every question-but I know that these kinds of questions and conversations are exactly what we need. More of us at the table determined to fix our schools.

Teachers: Tell Me What You Think (Guggenheim, 2010d) 


\section{pro.posições}

$e$-ISSN 1980-6248

My favorite thing is to hear from a teacher who's seen Waiting for "Superman". Teachers live it everyday so they get it-the good and the bad. And I am moved by all the reactions: the emotion, the criticism, the longing to help the kids in my documentary. Hearing this means the movie is working: the conversation is getting wider, bigger, deeper.

This film has sparked a lot of conversation, debate and even some disagreement. And that's exactly what we were hoping for.

At the time of the writing of this paper, Guggenheim had yet to directly respond to the 94 comments posted by teachers in response to his request, but it seems as though he was responding by changing the tenor and tone of the articles he wrote. The overwhelming majority of the posts could be classified as the decoding that we have mentioned. Not only did the comments reject the message the movie was trying to send, but they also disputed the facts the movie relies upon. It is fascinating to see Guggenheim's posts change from the first to the last. At first, Guggenheim implies that the discourse of educational reform has become too complicated causing us to lose sight of the core solution, hire better teachers. By the end, Guggenheim is acknowledging that the film has caused a complicated conversation and that this was the main goal of the film all along. It would indeed be interesting to hear what changed Guggenheim's approach to promoting this film. Each post was, at some level, a promotion, encouraging teachers to go see the movie. One wonders if the multiple decoding that took place in relation to his film had an effect. If he read the same comments presented here, one would think it had to factor in at some level.

Below are some of the comments to Guggenheim's (2010d) final post. While choosing what comments to post was difficult, as most were lengthy, the ones selected are included here in full to preserve each original author's voice.

Even if David Guggenheim didn't do a lot of research into what it's like to be a teacher, he has gotten a taste of our experience; he has been lambasted on his blog. After having one of your movies picked apart by teachers. Diane Ravitch and more, imagine, Mr. Guggenheim, what it is like, to have your whole carreer [sic] dismissed by people such as yourself-by people who consider themselves experts on your profession, but have no experience or education in the field. You told us what you really thought, and we have returned the favor. Got anything to say? I hope you haven't given up reading. We've endured years of scapegoating now, even had our names released by the Los Angeles Times as least effective teachers for anyone who has ever known us to see, and we're still standing. Do you think you'd have the stomach for our business? To listen to all the hatred for a top price of $70 \mathrm{~K}$ per year? (Hot Pierogi, 2010) 


\section{pro.posições}

$e$-ISSN 1980-6248

Here it is interesting to note that this writer rejects Guggenheim's claim to be on the side of teachers or that the film celebrates teachers in some way. In fact, this post sees the film as a continuation of a system that devalues the teaching profession.

Although I have chosen to send my own children to a public school, I am guilty of choosing a better school than that in which I currently teach. The children in my current school come from low socioeconomic backgrounds, have no preschool experiences, and have no basic academic or social skills upon entering kindergarten. My daughters have two full years of preschool and are growing up in a print-rich environment in which literacy and academic achievment [sic] are emphasized. My colleagues who teach kindergarten at my school consider it a successful day if no one eats a crayon, hits another student, or rips a book apart. My own children have entered school AT LEAST 3 years ahead of these students in terms of social skills and academics. And just getting rid of bad teachers will alleviate this problem?? This is what teachers are dealing with. We can't go into the homes of these children and force their parents to read to them. We can't force parents to teach the values of hard work, discipline, cooperation, and other social skills that allow for success in school. The achievement gap in socalled low performing schools doesn't just magically appear because the system is full of bad teachers who can't teach reading and math. It starts much, much earlier and is far more complex than that, and we're doing the best we can with the kids who come to us. As other have stated, we need to deal with the disease-poverty. (Zoey14, 2010)

This post tackles the film's obliviousness to social issues and how they play a part in the educational process. Whereas the film ignores or wishes to brush aside these issues as merely excuses, this post sees them as major hurdles.

In addition to its other problems, on full display in these comments, WFS is not a very good film, from a movie-making standpoint. Waiting for Superman hand-selects darling minority children as stars then stacks the deck against them in the narrative by slanting the data presented and suggesting that charter schools are the answer to our nation's failing public schools. There is no demonstration of how all public schools are failing, no vignettes of instruction or interaction in actual schools (either public or charter). Just the assertion that charters (which serve $4 \%$ of our nation's kids) are where poor kids—who can't afford private schools—ought to be, and some cheesy cartoon clips and recycled footage of idiotic teenagers as evidence [emphasis in the original] (nflanagan, 2010).

This post not only attacks the film's issues, but also its lack of research. It also notes something not noticed at first, the fact that there are few, if any, scenes of actual teaching or classroom interactions. This further supports the film's obscuring of the lived experiences involved in the educational process. 


\section{pro.posıções}

http://dx.doi.org/10.1590/1980-6248-2017-0028

\section{$e$-ISSN 1980-6248}

\section{Conclusion}

To embrace a cultural studies critique of education and this film's role in contemporary policy debates requires a return to the commitments of this admittedly political field. With an eye towards future research, relying on a cultural studies framework, it would be useful to conclude this paper by discussing four major themes of cultural studies (materialism, anti-essentialism, social constructivism, and radical contextuality) and how they provide a heuristic for using Waiting for Superman as the entrée into the investigation of the complexities of the current policies of education reform and the emerging social formations. The material aspect becomes clear when we see the stories of the young people and families portrayed in the film, and we can clearly understand the connections between their own lived experience and their education-both in terms of their present and their future. Parents make material sacrifices, the schools they attend are not meeting the real needs of the children, and a sense of future material benefit is expressed over and over as the purpose of school. However, those resisting the dominant narrative of the film also point to its misrepresentation of the lived reality of the schools themselves, be it the lives and work of teachers or the conditions of poverty and inequity in which these schools and communities reside. The appeal of a cultural studies critique lies in its insistence on the return to the material, even within an analysis of the discursive compositions that help construct those conditions.

Anti-essentialism, running deep throughout this paper, refers to the lack of guarantees in the process of reading texts and making meaning of the world. The intent of this paper is neither to paint its creators as solely good or bad nor to do the same with those that resist its representation. Meaning made of any text is negotiated and nested within a larger set of relations, and a cultural studies critique opens up the space for the nuance necessary to explore that complexity. In a similar way, social constructivism points to the ways in which knowledge is constructed amidst that set of relations and marks the ways in which meaning making happens dialogically and within communities of experience. A radical contextuality insists on the charge to place contemporary phenomena in historical context, searching for the roots of the codes and signifiers that make representation possible. Stuart Hall's encoding and decoding direct us to the importance of communication in social formations and their attendant critiques. As Grossberg (1997) states, "cultural studies must interrogate the ways in 


\section{pro.posıções}

$e$-ISSN 1980-6248

http://dx.doi.org/10.1590/1980-6248-2017-0028

which communication not only produces but also distorts or deviates from the homologous structuring of culture and social experience" (p.148).

It is with Benjamin and these cultural studies commitments in mind that we begrudgingly concede that Waiting for Superman might have an overall positive effect. While somewhat doubting the claim that Guggenheim intended the film to be a neutral conversation starter, the strong oppositional decoding that has taken place may push the film to a more neutral position than its original intent and, it must be noted, the conversation about public education in the US is more public than ever. However, if neoliberals continue to hold the film up as a symbol of free-market reforms, this could sway the balance. The key is to deny the film a place within the hegemonic structure or as the representation of its subject as a whole. This means that for scholars to truly work in a counterhegemonic way we cannot dismiss the film as a hegemonic entity without any merit worthy of critical engagement. It must be acknowledged as complex in meanings that result in material consequences for our schools. In the end, the film has fueled a conversation about educational reform. It is up to both sides to decide how they will use it to further their message. To be sure, the film itself will not decide who shapes educational reform; this is a question without guarantees that is left to a much more complicated, problematic process.

\section{References}

Carroll, T. G. (2007). The high cost of teacher turnover. National Commission on Teaching and America's Future.

Chilcott, L. (Producer), Guggenheim, D. (Director), \& Guggenheim, D., \& Kimball, B. (Writers). (2010). Waiting for Superman (Motion picture). United States: Paramount Pictures Entertainment.

Couric, K. (2010). @katiecouric: “Waiting for Superman”. @katiecouric. Retrieved December 9, 2010, from http://www.youtube.com/watch?v=L8jepdjqZIA

Dimitriadis, G., \& Carlson, D. (2003). Promises to keep: cultural studies, democratic education, and public life. New York; London: RoutledgeFalmer. 


\section{pro.posições}

$e$-ISSN 1980-6248

Fiske, J. (1989). Reading the popular. Boston: Unwin Hyman.

Gardner, D. P., Larsen, Y. W., Baker, W. O., Campbell, A., Crosby, E. A., Charles A. Foster, J., . . Wallace, R. (1983). A nation at risk: The imperative for educational reform. The National Commission on Excellence in Education.

Grossberg, L. (2010). Cultural studies in the future tense. Durham: Duke University Press.

Grossberg, L. (1997). Bringing it all back home: Essays on cultural studies. Durham, NC: Duke University Press.

Grossberg, L., Nelson, C., \& Treichler, P. A. (1992). Cultural studies. New York: Routledge.

Guggenheim, D. (2010a, November 1). Do you dither? [Blog post]. Retrieved December 13, 2010, from http://www.huffingtonpost.com/davis-guggenheim/do-youdither_b_776279.html

Guggenheim, D. (2010b, September 6). Repeat after me: We can't have great schools without great teachers [Blog post]. Retrieved December 13, 2010, from http://www.huffingtonpost.com/davis-guggenheim/repeat-after-me-we-canth_b_706090.html

Guggenheim, D. (2010c, October 3). The teacher who changed my life. [Blog post]. Retrieved December 13, 2010, from http://www.huffingtonpost.com/davis-guggenheim/aconversation-with-davis_b_748584.html

Guggenheim, D. (2010d, November 15). Teachers: Tell me what you think. [Blog post]. Retrieved December 13, 2010, from http://www.huffingtonpost.com/davisguggenheim/teachers-tell-me-what-you_b_783712.html

Hall, S. (1992). Cultural studies and its theoretical legacies. In L. Grossberg, C. Nelson, \& P. A. Treichler (Eds.), Cultural studies. New York: Routledge.

Hall, S. (1996). Encoding/decoding. In S. Hall, D. Hobson, A. Lowe, \& P. Willis (Eds.), Culture, media, language: Working papers in cultural studies, 1972-79. London: Routledge in association with the Centre for Contemporary Cultural Studies, University of Birmingham.

Harvey, D. (2005). A brief history of neoliberalism. Oxford; New York: Oxford University Press. 


\section{pro.posıções}

$e$-ISSN 1980-6248

HotPerogi. (2010). Re: Teachers: Tell me what you think [Blog comment]. Retrieved from (http://www.huffingtonpost.com/davis-guggenheim/teachers-tell-me-whatyou_b_783712.html).

Johnson, R. (1996). What is cultural studies anyway? In J. Storey (Ed.), What is cultural studies? A reader. London: Arnold.

nflanagan. (2010). Re: Teachers: Tell me what you think [Blog comment]. Retrieved from (http://www.huffingtonpost.com/davis-guggenheim/teachers-tell-me-whatyou_b_783712.html).

Pinar, W. (2004). What is curriculum theory? Mahwah, N.J.: L. Erlbaum Associates.

Ravitch, D. (2010). The death and life of the great American school system: how testing and choice are undermining education. New York: Basic Books.

Raymond, M., Brock, R., Cremata, E., Davis, D., Dickey, K., Cotter, M., . . Surratt, K. (2009). Multiple choice: Charter school performance in 16 states. Stanford, CA: Center for Research on Education Outcomes.

Rudick, C. K. (2012). Blending cultural studies and critical communication Pedagogy to examine Waiting for Superman. Paper presented at the American Educational Studies Association Annual Conference, Seattle, Washington.

Taubman, P. M. (2009). Teaching by numbers: deconstructing the discourse of standards and accountability in education. New York: Routledge.

United States Department of Education. (2010). NCLB: An overview. Retrieved December 10, 2010, from http://www2.ed.gov/nclb/landing.jhtml?src $=\ln$

Zoey14. (2010). Re: Teachers: Tell me what you think [Blog comment]. Retrieved from (http://www.huffingtonpost.com/davis-guggenheim/teachers-tell-me-whatyou_b_783712.html).

Submetido à avaliação em 20 de fevereiro de 2017; aceito para publicação em 17 de outubro de 2017. 